\title{
Кипро-минойские письмена. Взгляд со стороны.
}

Абстракт.

Эта статья посвящена проблемам происхождения кипро-минойского письма. Автор предлагает пересмотреть некоторые устоявшиеся с прошлого века представления о его происхождении. В том числе будут подвергнуты сомнению установки, касающиеся критской письменности как основы кипрского письма. Автор не считает, что критские иероглифические печати содержат текст, а полагает, что изображения являются отдельными пиктограммами, значение которых привязано к отдельной печати. И линейное письмо А не может происходить из них. Нет связи между начертаниями знаков линейного А и совершенно отличных от него по начертанию (стилю) знаков кипрского письма. Автор предполагает, что последнее возникло самостоятельно на основе пиктограмм неолита, и подверглось воздействию иероглифов Египта и лувийского письма. Поэтому мы считаем, что кипрское письмо не правомерно именовать минойским. Внимательное исследование Таблички из Энкоми, фрагмент 3 (Таблица 2), подвело нас к следующему заключению. Она не имеет отношения к другим фрагментам, найденным в том же месте (Таблица 3), и серьезно от них отличается. Мы выделили четыре самостоятельные зоны заполнения Фрагмента 3 (Таблица 9). При увеличении поверхности последней отчетливо становятся видны рисуночные изображения, названные нами «знаки второго уровня». Дополнительные изображения присутствуют в основном на Фрагменте 3, что делает этот артефакт уникальным произведением.

Ключевые слова: критские иероглифы, кипро-минойская письменность, дешифровка древних письмен, таблички из Энкоми, линейное письмо А и Б.

Более ста лет существует интерпретация происхождения Т. н. Кипро-минойского письма, идущей от времен британского исследователя А. Эванса. На Крите существовали две развитые письменности: линейное письмо А и Б. Более древнее, линейное А, по мнению Эванса, возникло из критских иероглифов. Из самого линейного письма А возникло линейное Б и письмо соседнего острова - Кипра. Мы предлагаем другой вариант происхождения письмен Крита, который очертим очень кратко, и поясним отсутствие связи кипрской системы письмен с соседним Критом.

1. Критские каменные печати, которых на острове найдено несколько сот, по мнению многих ученых 20 века, покрыты своеобразной письменностью. Считается, что это иероглифическая система, еще не дешифрованная. Язык ее не известен (Таблица 8: 2).

Со своей стороны замечу, что не считаю изображения на печатях письменностью. Это декоративные изображения, вариант украшений, тип которых, видимо, был модным на острове во 2 тысячелетии до н. э. Скажем, такие знаки отличие заказывались семьями, и значки могли быть связаны с определенной деятельностью главы семьи и другими членами дома. И это не письменность, которую можно прочитать. Среди возможных «доказательств», как нам кажется, можно сослаться на значительную схожесть групп печатей между собой. Есть один вариант печатей, который, скорее всего срисован с картушей древнего Египта (Таблица 8: 2). Еще одно соображение в подтверждение нашей идее: почти все печати содержат три знака. Что уже указывает на декоративность скорее, чем на функциональность. Для примера сошлемся на Хараппские печати, где количество знаков варьируется от одного до десяти и более (Таблица 8: 1). Таким образом, мы заключаем, что между каменными печатями и возникновением линейного письма А нет связи, и это далекие друг от друга изобразительные системы. По нашему мнению, линейные письмена Крита возникли каким-то другим путем. Что не является на момент темой нашего исследования.

2. Крупнейшими находками среди кипрских надписей представляются на момент т. н. Таблички из Энкоми (Восточный Кипр). Больше десятка крупных кусков, из обожженной глины, покрытых с двух сторон своеобразными знаками. В литературе можно прочитать, что это части одной большой таблицы (артефакта). Из около 10 отдельных фрагментов, находящихся в разных музеях. С нашей точки зрения это не так. Подробное исследования самых известных частей находки из Энкоми - Фрагмента 2, сейчас в музее Никосии (Таблица 3) и Фрагмента 3 из Лувра (Таблица 2) - привело нас к заключению, что фрагмент 3 - это совершенно другое явление, имеющее много серьезных отличий от других фрагментов (Таблицы 2, 3, 4). Мы нашли на фрагменте четыре поверхности. Они различаются по

1. глубине вдавливания основных знаков

2. цвету поверхности

3. плотности расположения знаков

4. толщине слоя для письма.

Так, сегмент 1 представляется бледно-розовым, глубина знаков минимальная, и они расположены очень редко. Такое впечатление, что поверхность знаков после их нанесения и затвердевания скоблилась. Сегмент 2 начинается под первым и идет почти до самого низа, постепенно расширяясь в правую сторону. По количеству значков он главный, плотность значков наибольшая. Сегмент 3, самый 
коричневый, расположен у правого края, значки беспорядочно написаны. Сегмент 4 представляется самым красивым и своеобразным. Такое впечатление, что сначала было отверстие (отлом), который заполнили светлой глиной, этот слой не только по цвету другой, и выше всех остальных сегментов. Самый маленький сегмент 5 левый нижний угол, где меньше 10 значков, часть которых нарисована скорее, чем выдавлены.

3. Исключительной особенностью фрагмента 3 является то, что нами названо «знаки второго уровня». Если внимательно рассматривать поверхность, особенно с применение лупы, то наблюдается такой феномен. Есть основные знаки: это те, что выдавлены специальными палочками так, чтобы образовались многочисленные знаки, составленные из «длинных капелек», более или менее ромбовидных, располагающихся вертикально, и несколько реже расположенных - по горизонтали. Набор значков на фрагменте 3 мал, наверное поэтому ученые решили, что письмо - слоговое. Теперь о знаках второго плана. Их значительно больше, чем «основных» и каждый «слог» как бы облеплен мелкими изображениями, в которых отчетливо угадываются головы, носики, рога, ножки так, что они все вместе составляют целые картины, где можно найти коз, птиц, рыб, и других самых разных существ (Таблица 4). Имеет ли этот «дополнительный слой прорисованных знаков связь с основным написанным текстом? Может быть, это еще один текст поверх основного текста? Или это вариант «украшения» письма. Может быть, это один из оберегов, защищающий текст и знаки? (Таблицы 2, 4)

Замечу, что кроме мелких существ, из которых в основном состоит фон «второго уровня», есть четыре знака, которые выделяются среди других. Такое впечатление, что это могли быть разделительные знаки смысловых кусков. Это легко заметные крупные значки сегмента 3, которые названы автором «Лось» и «Обелиск» или «Фонтан» (Таблица 9). Из расположенных по вертикали более мелкие «Рыба» (сегмент 2) и «Птица» (сегмент 4).

Табличка из Энкоми, известная как Фрагмент 2 сделана иначе (Таблица 3). Текст унифицирован, словно сделан более профессиональной рукой. Есть знаки, схожие с теми, что мы видим во Фрагменте 3, есть уникальные знаки. При увеличении видно, что на Фрагменте 2 нет такого изобилия дополнительных образов , хоть отдельные значки тоже «приукрашены» глазами, носами и лапами, что скорее исключение, чем правило (Таблица 3). Традиция добавлять на поверхность привлекших внимание древнего человека камней разные мелкие значки существовала в неолите. Некоторые иероглифы древнего Египта тоже имеют дополнения в углах или на поверхности. Массу таких дополнений имеют значки Фестского диска (Таблица 10).

4. В решении вопроса происхождения слогового письма Кипра мы двигались в трех возможных направлениях: автохтонное письмо, египетские корни, хетто-лувийское происхождение.

1. кипрское письмо - явление местное, возникшее на острове в результате долгого процесса превращения пикрограмм палео- и неолитического времени в своеобразные знаки. Для поиска аналогий мы использовали самые известные значки каменного века из Тассили, Северная Африка, из-за их выразительности и многочисленности примеров. Климат региона позволил сохраниться

многочисленным неолитическим цветным изображениям, допустим, что неолитические изображения на Кипре могли быть близки к североафриканским. На фрагменте 3 (Таблица 1 и 4) можно заметить, что скорее всего историческое развитие письменности шло от натуралистических рисунков, части которых заменялись на более простые в изображении на глине знаки-капельки.

2. Археологическое датирование табличек дает нам время около 1500 г. до н.э. Исследование разных видов письма этого времени на соседних территориях приводит к нескольким выводам. Ближайшим развитым соседом для Кипра был Египет фараонов. И детальное сравнение иероглифики последних со знаками фрагмента 3 дает интересные результаты. Мы составили две таблицы (можно было сделать значительно больше), сравнений знаков двух языковых систем (Таблица 6 и 7). Замечаем, что ряд знаков имеет несомненное сходство, откуда мы делаем вывод о воздействии письменной системы Египта на знаковую систему Кипра хотя бы визуально. Мы не отрицаем, что влияние могло быть не только на внешнем уровне, что выразилось с сходстве изображения знаков. Может быть и более глубокая связь между письменностями.

3. Еще одна письменная система привлекла наше внимание - это Лувийские иероглифы. При сравнении с кипрской оказались некоторые совпадения. Все, что написано выше о египетских знаках, справедливо для лувийских (Таблица 5). То есть можно говорить о воздействии иероглифов из Малой Азии на уровне формы.

Возможно, аутентичная система письма древнего Кипра в какой-то мере подвергалась влиянию своих мощных соседей, сохранив при этом своеобразие своей письменной системы.

Заключение.

Наши выводы относительно Фрагмента 3 (Таблица 2) можно суммировать: табличка по времени древнее, чем Фрагмент 2 (Таблица 3), Фрагмент 4 и другие известные тексты с т. н. кипро-минойским письмом. Возможно, это своеобразный учебный текст, где пробовались разные варианты значков, на что указывает разноцветная и разнофактурная поверхность фрагмента. Связь Фрагментов 2 и 3 очевидна, и по нашему мнению письмо Фрагмента 2 пользовалось знаками Фрагмента 3. По нашему мнению, письмо возникло на острове Кипр из неолитических пиктограмм, и не имеет отношения к культуре Крита. Некоторое влияние на начертания знаков оказали иероглифы Египта и хетто-лувийские письмена. 
Таблица 10. Дополнительные изображения на основном значке Extra signs on the main pictures
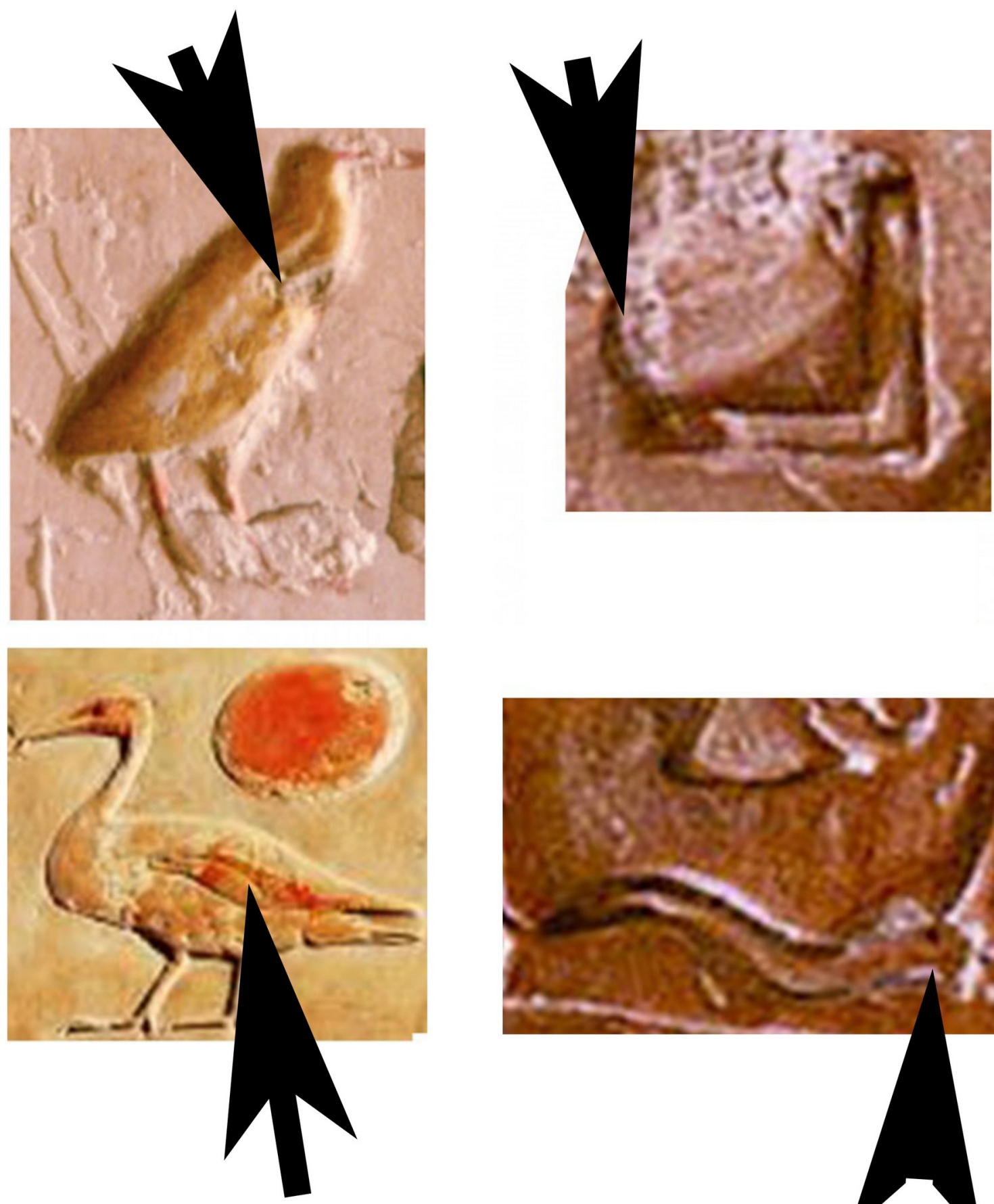

1. Hieroglyphs from Egypt

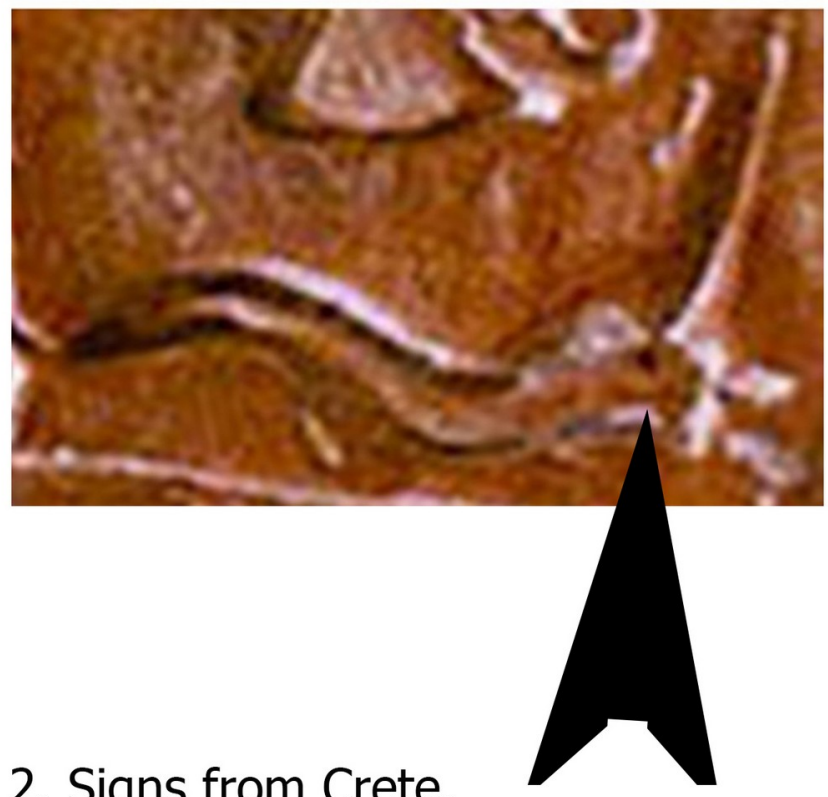
Faestos Diskos 